(A)

\title{
Pengaruh Strategi Pembelajaran Relating, Experiencing, Applying, Cooperating, Transferring (REACT) terhadap Keterampilan Proses Sains Siswa (The Effect of Relating, Experiencing, Applying, Cooperating, Transferring (REACT) Learning Strategy on Student Science Process Skills)
}

\author{
Syintia*, Budhi Akbar, Luthpi Safahi, Susilo Susilo \\ Program Studi Pendidikan Biologi FKIP Universitas Muhammadiyah Prof. DR. HAMKA, Jakarta, Indonesia \\ *Corresponding author: syintia18@gmail.com
}

Accepted: 16 September 2018 - Approved: 26 September 2018 - Published: 30 September 2018

\begin{abstract}
This study aims to determine the effect of Relating, Experiencing, Applying, Cooperating, Transferring (REACT) learning strategies on students' science process skills. This research was carried out in SMA Negeri 11 Bekasi City from April to May 2017. The method used in this study was Quasi Experiment, with the Posttest Only Control Design research design. The target population is all students of class X MIA totaling 240 students. The sampling technique used Cluster Random Sampling, and obtained the X MIA 2 class as the experimental class and X MIA 3 class as the control class. Data collection is done by using multiple choice tests to measure 9 indicators of student science process skills. Hypothesis testing using the $\mathrm{t}$ test at a significance level $\alpha=1 \%$, obtained tcount $=3.06>\mathrm{t} 0.99=2.38$, which means that $\mathrm{H} 0$ is rejected, so there is a very significant effect on both groups. So, it can be concluded that the use of REACT (Relating, Experiencing, Applying, Cooperating, Transferring) learning strategies has an effect on students' science process skills.
\end{abstract}

Keywords learning strategies of REACT, science process skills, ecosystem

\begin{abstract}
ABSTRAK Penelitian ini bertujuan untuk mengetahui pengaruh strategi pembelajaran REACT (Relating, Experiencing, Applying, Cooperating, Transferring) terhadap keterampilan proses sains siswa. Penelitian ini dilaksanakan di SMA Negeri 11 Kota Bekasi pada bulan April hingga Mei 2017. Metode yang digunakan dalam penelitian ini adalah quasi experiment, dengan desain penelitian posttest only control design. Populasi target yaitu seluruh siswa kelas X MIA berjumlah 240 siswa. Teknik pengambilan sampel menggunakan cluster random sampling, dan diperoleh kelas X MIA 2 sebagai kelas eksperimen dan kelas X MIA 3 sebagai kelas kontrol. Pengumpulan data dilakukan dengan menggunakan tes pilihan ganda untuk mengukur 9 indikator keterampilan proses sains siswa. Uji hipotesis menggunakan uji t pada taraf signifikansi $\alpha=1 \%$, diperoleh $t_{\text {hitung }}=3,06>\mathrm{t}_{0,99}=2,38$, yang berarti $\mathrm{H}_{0}$ ditolak, sehingga terdapat pengaruh yang sangat signifikan terhadap kedua kelompok. Jadi, dapat disimpulkan bahwa penggunaan strategi pembelajaran REACT (Relating, Experiencing, Applying, Cooperating, Transferring) berpengaruh terhadap keterampilan proses sains siswa.
\end{abstract}

Kata kunci strategi pembelajaran REACT, Keterampilan Proses Sains (KPS), ekosistem

\section{PENDAHULUAN}

Pemerintah Indonesia telah melakukan upaya untuk meningkatkan kualitas sumber daya manusia (SDM) melalui peningkatan kualitas pendidikan. Salah satu upaya yang ditempuh pemerintah dalam meningkatkan kualitas pendidikan yaitu melalui penyempurnaan kurikulum. Saat ini kurikulum yang berlaku yaitu Kurikulum 2013.

Pelaksanaan kegiatan pembelajaran yang berdasarkan Kurikulum 2013 haruslah menggunakan pendekatan saintifik. Pendekatan saintifik dalam proses pembelajaran meliputi kegiatan mengamati, menanya, mengumpulkan data, mengasosiasi serta melakukan komunikasi (Sani, 2014). Melalui pendekatan saintifik, para siswa didorong untuk menggunakan keterampilan yang dimiliki seperti halnya keterampilan para ilmuwan dalam memecahkan masalah (Amirullah \& Susilo, 2018). Keterampilan yang digunakan para ilmuwan untuk memecahkan masalah sekaligus meningkatkan pemahamannya disebut keterampilan proses sains. Keterampilan proses merupakan keseluruhan keterampilan ilmiah yang terarah, dapat digunakan untuk menemukan suatu konsep, prinsip, dan teori (Trianto, 2015). Keterampilan proses yang biasa digunakan dalam pembelajaran IPA adalah Keterampilan Proses Sains (KPS).

Biologi sebagai IPA atau Sains bukan hanya terdiri dari produk ilmiah yaitu kumpulan fakta dan prinsip, namun biologi juga mengandung suatu proses bagaimana cara memperoleh fakta dan prinsip tersebut melalui pendekatan ilmiah (Fatonah \& Prasetyo, 2014). Jadi dalam pembelajaran biologi seyogyanya menggunakan dan mengembangkan keterampilan proses sains siswa. 
Menurut data survei yang dilakukan oleh Programme for International Student Assessment (PISA) pada tahun 2015 dari 76 negara, Indonesia menempati posisi ke 69 di bidang Matematika dan Sains (Coughlan, 2015). Posisi tersebut mengindikasikan bahwa Indonesia hanya mampu mengenal sebagian fakta-fakta dasar dari ilmu sains. Atau bermakna keterampilan proses sains siswa Indonesia belum sepenuhnya terasah dengan baik. Padahal menurut Aktamis \& Ergin (2008), pada dasarnya seseorang telah menggunakan keterampilan dasar proses sains dalam setiap pemikirannya. Rendahnya keterampilan proses sains siswa di sekolah diduga karena kebanyakan guru masih bertahan pada cara yang sama dalam mengajar. Menurut Selamet \& Suma (2013), fakta di lapangan menunjukkan bahwa proses pembelajaran sains selama ini masih terlihat berpusat pada guru (teacher oriented) dengan metode yang digunakan adalah ceramah sehingga siswa tidak terlatih untuk aktif sendiri membangun pengetahuan, namun siswa cenderung pasif yang hanya menerima pengetahuan dari guru.

Sebagai salah satu solusinya untuk meningkatkan keterampilan proses sains siswa adalah dengan memperbaiki proses pembelajaran. Salah satu strategi pembelajaran yang dapat digunakan adalah strategi relating, experiencing, applying, cooperating, and transferring (REACT), yang dijabarkan oleh CORD (Center of Occupational Research and Development) di Amerika. Strategi REACT merupakan salah satu strategi pembelajaran kontekstual yang memberikan kesempatan kepada siswa untuk belajar mandiri, membuat siswa termotivasi untuk belajar, mampu bekerja sama, dan proses pembelajaran disajikan sesuai dengan konteks kehidupan mereka (Wasis \& Nurzaini, 2016). Proses pembelajaran dengan strategi REACT akan menghubungkan konsep yang akan dipelajari dengan kehidupan nyata. Siswa akan mendapatkan pengetahuannya melalui pengalaman langsung, sehingga pengetahuan yang didapatkan akan lebih bermakna. Serangkaian fase dari REACT dipandang dapat meningkatkan keterampilan proses sains yang dimiliki oleh siswa (Selamet \& Suma, 2013).

Berdasarkan uraian di atas serta melihat manfaat yang diperoleh melalui penerapan strategi REACT, peneliti mengadakan penelitian dengan judul "Pengaruh Strategi Pembelajaran REACT terhadap Keterampilan Proses Sains Siswa".

\section{METODE}

Tempat yang dijadikan penelitian berlokasi di SMAN 11 Kota Bekasi yang beralamat di Jalan Wibawa Mukti, Kav. PATI AURI, Jatisari, Jati Asih, Kota Bekasi. Penelitian ini menggunakan penelitian kuantitatif, dengan metode quasi experiment, dimana banyak variabel luar yang dapat mempengaruhi eksperimen. Populasi target dalam penelitian ini adalah seluruh siswa SMAN 11 Kota Bekasi kelas X IPA semester genap tahun ajaran 2016/2017 sebanyak 240 siswa.

Sampel diambil dari populasi menggunakan teknik cluster random sampling. Penelitian ini diperoleh dua kelas yaitu kelas kontrol X MIA 3 dan kelas eksperimen X MIA 2. Pada kedua kelas tersebut diberikan perlakuan yang berbeda. Strategi pembelajaran REACT diimplementasikan pada kelas eksperimen, sedangkan pembelajaran konvensional diimplemtasikan pada kelas kontrol, masingmasing dilaksanakan sebanyak 4 pertemuan.

Penelitian ini menggunakan desain posttest only control design. Instrumen yang digunakan dalam penelitian ini berupa silabus kelas X mata pelajaran biologi, RPP dan soal pilihan ganda berupa posttest untuk mengukur keterampilan proses sains siswa di kelas kontrol dan kelas eksperimen. Instrumen soal posttest sebelumnya telah dilakukan uji coba instrumen dengan menguji validitas, reliabilitas, tingkat kesukaran, daya pembeda. Nilai posttest antara kelas eksperimen dan kelas kontrol kemudian akan dianalisis menggunakan uji prasyarat normalitas dan homogenitas, selanjutnya dengan pengujian hipotesis menggunakan uji t.

\section{HASIL DAN PEMBAHASAN}

Data yang diperoleh dan dianalisis dalam penelitian ini berupa skor hasil posttest keterampilan proses sains siswa. Berikut tersaji dalam Tabel 1.

Tabel 1. Data Hasil Posttest Keterampilan Proses Sains Kelas Kontrol dan Eksperimen

\begin{tabular}{ccccc}
\hline Kelas & Rata-rata & SD & Min. & Max. \\
\hline Kontrol & 67,9 & 9,83 & 47 & 87 \\
Eksperimen & 74,3 & 8,88 & 57 & 90 \\
\hline
\end{tabular}

Hasil posttest Tabel 1, menunjukkan skor rata-rata kelas eksperimen lebih tinggi dibandingkan dengan kelas kontrol sehingga terdapat perbedaan hasil posttest antara kedua kelas.

Selain itu, untuk melihat adanya perbedaan bisa dilakukan dengan analisis data. Analisis data yang digunakan yaitu analisis uji prasyarat dan analisis uji hipotesis. Analisis uji prasyarat terdiri dari dua yaitu uji normalitas dan homogenitas. Uji normalitas menggunakan rumus Chi Kuadrat dan didapatkan bahwa data berdistribusi normal. Setelah data kedua data normal, maka dilanjutkan dengan uji homogenitas dengan metode uji Fisher dan didapatkan data kedua kelompok homogen. Untuk melihat adanya perbedaan antara kedua kelas, digunakan uji hipotesis yaitu uji-t dengan rumus Separated Varian, hasil yang diperoleh tersaji dalam Tabel 2.

Tabel 2. Hasil Perhitungan Uji-t

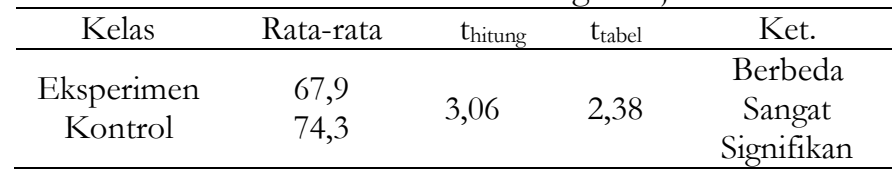

Hasil uji t pada Tabel 2, menunjukkan bahwa nilai thitung $=3,06>$ ttabel $=2,38$, maka $\mathrm{H}_{0}$ ditolak, artinya terdapat perbedaan yang sangat signifikan antara kelas eksperimen dan kelas kontrol. Perolehan nilai rata-rata posttest siswa kelas eksperimen terlihat lebih besar, yaitu 74,30 dibandingkan dengan kelas kontrol yang tidak diberi perlakuan strategi REACT dengan nilai rata-rata sebesar 67,90, membuktikan bahwa strategi REACT memberikan pengaruh positif untuk meningkatkan keterampilan proses sains siswa di kelas eksperimen. 
Selain dilihat dari perbedaan hasil posttest secara keseluruhan, keterampilan proses sains juga dapat dilihat dari kemampuan siswa dalam menjawab pertanyaan pada setiap indikator keterampilan proses sains. Berikut nilai rata-rata perbandingan persentase setiap indikator keterampilan proses sains kelas eksperimen dan kelas kontrol, seperti yang tersaji pada Gambar 1.

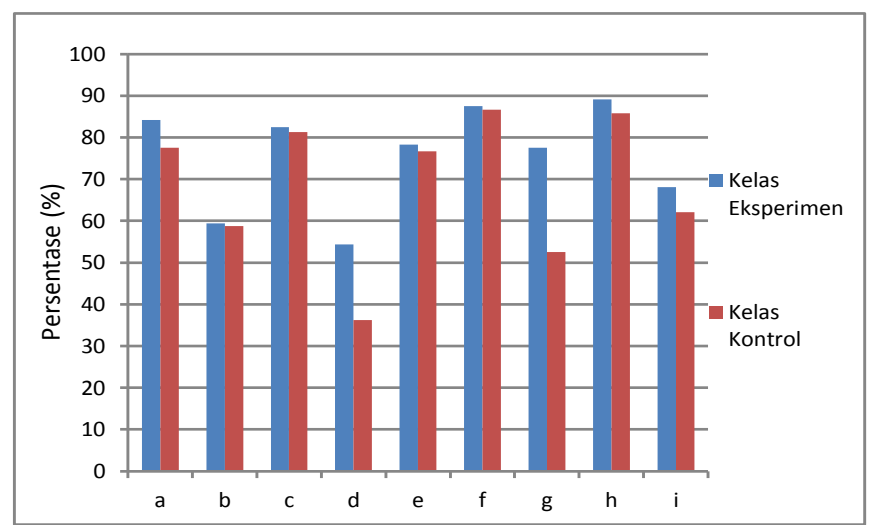

Keterangan: (a) observasi, (b) klasifikasi, (c) aplikasi, (d) prediksi, (e) komunikasi, (f) inferensi, (g) hipotesis, (h) mengajukan pertanyaan, (i) mendeskripsikan hubungan antarvariabel.

Gambar 1. Perbandingan Persentase Setiap Indikator Keterampilan Proses Sains pada Kelas Eksperimen dan Kelas Kontrol

Gambar 1 menunjukkan bahwa perbandingan persentase keterampilan proses sains siswa kelas eksperimen memiliki keterampilan proses sains yang lebih baik dari pada kelas kontrol pada setiap indikatornya. Secara umum pencapaian keterampilan proses sains pada kelas eksperimen dalam materi ekosistem lebih tinggi dibandingkan dengan kelas kontrol dikarenakan pembelajaran dalam kelas eksperimen dilakukan dengan menggunakan strategi REACT yang membiasakan siswa pada aktivitas metode ilmiah dan aktif saat pembelajaran berlangsung. Hal tersebut sesuai dengan pernyataan Nurzaini \& Wasis (2016), bahwa siswa akan secara aktif dalam mencari pengetahuan dengan menggunakan metode ilmiah sehingga siswa akan terbiasa melatihkan keterampilan proses sains yang dimilikinya.

Keterampilan proses sains yang memiliki selisih paling besar antara kelas eksperimen dan kelas kontrol adalah keterampilan berhipotesis sebesar 25\%. Hal tersebut dikarenakan pada kelas eksperimen proses pembelajaran terjadi tahap relating. Menurut Crawford (2001), relating adalah belajar dalam konteks pengalaman kehidupan nyata atau pengetahuan yang sebelumnya telah ada. Tahap ini guru memberikan sebuah masalah tentang ekosistem yang berhubungan dengan kehidupan sehari-hari, kemudian siswa diminta merumuskan sebuah pertanyaan dan jawaban sementara siswa. Sedangkan pembelajaran pada kelas kontrol walaupun telah menggunakan pendekatan saintifik dalam proses pembelajarannya, setelah siswa menanya atau mengajukan pertanyaan maka proses selanjutnya adalah mengumpulkan data tanpa membuat suatu hasil jawaban sementara. Itulah yang membuat hasil keterampilan berhipotesis kelas kontrol menjadi jauh di bawah kelas eksperimen.
KPS yang dikembangkan pada tahap relating yaitu keterampilan mengajukan pertanyaan, keterampilan merumuskan hipotesis, keterampilan prediksi, dan mendeskripsikan hubungan antar variabel. Pada kelas eksperimen hasil keterampilan tersebut secara urut sebesar $89,17 \%, 77,50 \%, 54,38 \%$, dan 68,13\%, sedangkan pada kelas kontrol hasil keterampilan tersebut secara urut sebesar 85,83\%, 52,50\%, 36,25\%, dan 62,12\%. Selisih paling kecil dari hasil KPS tersebut adalah keterampilan mengajukan pertanyaan dikarenakan pada model konvensional pada kegiatan awal pertemuan siswa juga selalu bertanya tentang materi yang akan dipelajarinya. Menurut Sani (2014), sebelum topik pembahasan akan dipelajari, siswa harus dilatih untuk merumuskan pertanyaan karena sangat penting untuk meningkatkan rasa ingin tahu mereka serta mengembangkan pengetahuan awal yang telah dimiliki.

Selanjutnya pada tahap experiencing siswa akan menemukan pengetahuannya sendiri melalui sebuah pengalaman langsung. Crawford (2001), mengatakan bahwa strategi experiencing dapat membantu siswa untuk membangun konsep baru dengan cara mengkonsentrasikan pengalaman-pengalaman yang terjadi dalam kelas melalui eksplorasi, pencarian, dan penemuan. Menurut Ultay \& Calik (2016), fase experiencing membutuhkan hubungan konteks pada fase pertama yaitu relating, maksudnya pada fase ini pengalaman haruslah berdasarkan konteks yang dijelaskan pada fase pertama. Tahap experiencing akan membantu siswa dalam meningkatkan keterampilan mengamati serta mengelompokkan dalam sebuah percobaan. Pengalaman langsung siswa akan berupa sebuah praktek atau percobaan sederhana dengan memperoleh informasi sesuai yang diarahkan oleh guru. Dalam pelaksanaannya, guru akan memberikan Lembar Kerja Peserta Didik (LKPD) untuk membantu siswa dalam melakukan sebuah praktikum. Menurut Afifi (2014), kegiatan yang berlangsung dalam proses pengajaran akan membuat siswa aktif untuk menemukan keterkaitan materi pelajaran dengan kehidupan sehari-hari. Hal ini senada dengan yang diutarakan Sanjaya (2013), yang mengemukakan bahwa dalam proses pembelajaran siswa diarahkan untuk mengembangkan kemampuan berpikirnya serta mencari tahu dan menemukan jawaban sendiri dari suatu permasalahan. Hasil KPS yang diperoleh pada kelas eksperimen secara urut adalah $84,17 \%$ dan 59,38\%. Sedangkan hasil pada kelas kontrol yang didapat secara urut adalah $77,50 \%$ dan 58,75\%. Keterampilan mengelompokkan memiliki selisih hasil yang sedikit dikarenakan mengelompokkan termasuk ke dalam KPS tingkat dasar sehingga untuk anak SMA keterampilan tersebut merupakan keterampilan yang harus sudah dikuasai.

Selanjutnya adalah fase applying, yang merupakan proses belajar dengan menggunakan pengetahuan yang telah didapat untuk kegunaannya (Ibrahim, 2014). Tujuan dari adanya fase applying atau menerapkan adalah agar siswa dapat mengembangkan potensi intelektual yang dimilikinya untuk dipraktekkan dalam situasi yang nyata (Siregar \& Nara, 2010). Pada tahap ini siswa mengerjakan latihan soal tentang ekosistem yang berkaitan dengan kehidupan seharihari. Soal terdapat dalam LKPD yang telah diberikan oleh 
guru. Tahap ini akan membangun keterampilan menerapkan konsep atau aplikasi. Tahap ini akan membangun keterampilan menerapkan konsep atau aplikasi. Pada kelas eksperimen diperoleh hasil sebesar $82,50 \%$, sedangkan pada kelas kontrol sebesar 81,25\%. Selisih persentase hasil tersebut tidak terlalu jauh dikarenakan pada kelas kontrol siswa sama-sama terlatih menerapkan konsep yang telah dipelajarinya pada soal yang terdapat pada LKPDnya.

Selanjutnya adalah tahap cooperating atau bekerja sama. Menurut Crawford (2001), fase cooperating merupakan pembelajaran dalam konteks yang saling berbagi, merespon dan berkomunikasi dengan sesama temannya untuk membentuk pemahaman sendiri, sehingga apa yang dipelajarinya akan lebih bermakna. Pada tahap ini siswa diharapkan dapat bekerja sama dengan tiga atau empat orang dalam satu kelompok. Pada tahap cooperating siswa akan berdiskusi untuk menyimpulkan hasil pengamatan yang telah dilakukan. Keterampilan menyimpulkan pada kelas eksperimen sebesar 87,50\%, sedangkan pada kelas kontrol sebesar $86,67 \%$. Hal tersebut tidak berbeda jauh dikarenakan pada kelas kontrol di akhir pembelajaran siswa juga berdiskusi untuk menyimpulkan apa yang telah mereka pelajari pada hari itu.

Selanjutnya adalah tahap transferring atau alih pengetahuan. Menurut Crawford (2001), transferring adalah strategi pembelajaran saat siswa menggunakan pengetahuan ke dalam konteks atau situasi yang baru. Tahap ini dilakukan dengan kegiatan presentasi di depan kelas ataupun dengan mengemukakan pendapatnya di depan siswa yang lainnya. Keterampilan proses sains yang bisa ditingkatkan dalam tahap ini yaitu keterampilan menyimpulkan serta mengkomunikasikan.

Hasil yang diperoleh pada kelas eksperimen keterampilan komunikasi sebesar 78,33\%, sedangkan kelas kontrol sebesar $76,67 \%$. Selisih hasil tersebut bernilai kecil dikarenakan pada kelas kontrol di akhir pertemuan juga terdapat kegiatan mengkomunikasikan apa yang telah didapat pada pembelajaran hari itu. Walaupun selisih tersebut bernilai kecil, strategi REACT tetap lebih efektif membangun keterampilan komunikasi. Hal ini sesuai dengan pernyataan Utami et al. (2016), bahwa strategi REACT efektif untuk mengajarkan berbicara di depan umum dikarenakan para murid mencoba untuk mengkomunikasikan kembali tentang percobaan atau praktek yang telah dilakukan pada tahap experiencing. Menurut Paulin \& Suneson (2012) adanya tahap transferring akan memberikan kesempatan kepada murid untuk mengungkapkan ide mereka, pendapat dan mempertahankannya di depan umum akan membantu membuat kesimpulan pada topik yang telah dibahas. Dengan demikian, dapat dikatakan strategi pembelajaran REACT memiliki pengaruh yang baik dalam peningkatan keterampilan proses sains siswa.

\section{SIMPULAN}

Penggunaan strategi pembelajaran REACT berpengaruh terhadap keterampilan proses sains siswa pada materi ekosistem. Penerapan strategi pembelajaran
REACT dapat meningkatkan KPS siswa jika dibandingkan dengan pembelajaran konvensional.

\section{REFERENSI}

Afifi, J. (2014). Inovasi-Inovasi Kreatif Manajemen Kelas \& Pengajaran Efektif. Jogjakarta: Diva Press.

Aktamis, A., \& Ergin, O. (2008). The Effect of Scientific Process Skills Education on Students' Scientific Creativity, Science Attitudes and Academic Achievements. Journal Asia-Pacific Forum of Science Learning and Teaching. Vol 9(1) : 1-21.

Amirullah, G. \& Susilo, S. (2018). Pengembangan Media Pembelajaran Interaktif Pada Konsep Monera Berbasis Smartphone Android. Wacana Akademika. Vol. 2(1): 38-47.

Coughlan, S. (2015). Asia Tops Biggest Global School Rankings. [Online]. Tersedia: www.bbc.com/news/business32608772 [Diakses pada 25 April 2017].

Crawford. (2001). Teaching Contextually (Research, Rationale, and Techniques for Improving Student Motivation and Achievement in Mathematics and Science). United States of America. CORD Communications, Inc.

Fatonah, S. \& Prasetyo, K. (2014). Pembelajaran Sains. Yogyakarta: Ombak Press.

Ibrahim, N. (2014). Perencanaan Pembelajaran Teoretis dan Praktis. Jakarta: Mitra Abadi.

Paulin, D. \& Suneson, K. (2012). Knowledge Transfer, Knowledge Sharing, and Knowledge Barries - Three Blurry Terms in KM. The Electronic Journal of Knowledge Management. 10(1) : 81-91.

Sani, R. (2014). Pembelajaran Saintifik untuk Implementasi Kurikulum 2013. Jakarta: Bumi Aksara.

Sanjaya, W. (2013). Strategi Pembelajaran Berorientasi Standar Proses Pendidikan. Jakarta: Penerbit Kencana.

Selamet, S. \& Suma. (2013). Pengaruh Model Pembelajaran Kontekstual REACT terhadap Pemahaman Konsep Fisika dan Keterampilan Proses Sains Siswa Kelas VIII SMP. E-Journal Program Pascasarjana Universitas Ganesha Program Studi IPA. 3(1) : 1-12.

Siregar \& Nara. (2010). Teori Belajar dan Pembelajaran. Bogor: Ghalia Indonesia.

Trianto. (2015). Model Pembelajaran Terpadu. Jakarta: Bumi Aksara.

Ultay, N. \& Calik, M. (2016). A Comparison of Different Teaching Designs of Acids and Bases Subject. Eurasia Journal of Mathematics, Science, \& Technology Education. 12(1) : 57-86.

Utami, W.S., Sumarmi, S., Ruja, I.N. \& Utaya, S. (2016). REACT (Relating, Experiencing, Applying, Cooperative, Transferring) Strategy to Develop Geography Skills. Journal of Education and Practice. 7(17): 100-104.

Wasis \& Nurzaini, M. 2016. Penerapan Pembelajaran Kontekstual dengan Strategi REACT untuk Meningkatkan Keterampilan Proses Sains Siswa pada Materi Fluida Statis di Kelas X SMAN 1 Gedangan. Jurnal Inovasi Pendidikan Fisika. 5(2): 1116. 